\title{
Current taxonomic studies on the diatom flora (Bacillariophyceae) of the Bolivian Altiplano, South America, with possible consequences for palaeoecological assessments
}

\author{
EDUARDO A. MORALES ${ }^{1 *}$, CARLOS E. WETZEL ${ }^{2}$, SINZIANA F. RIVERA ${ }^{1}$, BART VAN DE VIJVER ${ }^{3}$ \& LUC ECTOR $^{2}$ \\ ${ }^{1}$ Herbario Criptogámico, Universidad Católica Boliviana San Pablo, Calle M. Márquez esq. Plaza Jorge Trigo s/n, PO Box 5381, Cochabamba, Bolivia \\ ${ }^{2}$ Public Research Centre - Gabriel Lippmann, Department of Environment and Agro-biotechnologies (EVA), 41 rue du Brill, L-4422 Belvaux, \\ Luxembourg \\ ${ }^{3}$ Botanic Garden Meise, Department of Bryophyta \& Thallophyta, Domein van Bouchout, B-1860, Meise, Belgium \\ *Corresponding author (e-mail: edu_mora123@outlook.com)
}

\begin{abstract}
The present investigation is based on detailed taxonomical analyses combining light microscopy (LM), scanning electron microscopy (SEM) and critical reviews of publications and type material. This method revealed a higher number of diatom taxa than that reported for the Altiplano, reports that are based on LM and SEM, but force-fitting the taxa into their European relatives. It also became evident that some taxa often reported from the Altiplano do not occur or are less common in this region and that misidentifications are the consequence not only of force-fitting, but also of misinterpretation of the original protologues and illustrations (taxonomic concept drift). These findings have important repercussions on past palaeoecological assessments for the Altiplano, which have been based on ecological information for taxa developing in ecosystems of highly contrasting conditions. Here we present the case of three araphid diatoms, which were reported as known taxa from Europe and elsewhere, but in fact correspond to taxa described as new for the Altiplano or unpublished taxa. It is recommended that: (1) a flora for this region is developed utilizing sound microscopical data and reviewing pertinent type material, (2) key common taxa used for past palaeoecological studies in the Altiplano are reviewed using a taxonomically thorough and critical method, and (3) future palaeoecological studies for the Andes are supported by prior detailed taxonomical analysis.
\end{abstract}

KEYWORDS: Bacillariophyceae, diatoms, palaeoecology, palaeolimnology, type material

\section{INTRODUCTION}

Montagne (1839) made the first identifications of diatoms from Bolivia from material collected from the Pacific coast by Alcide d'Orbigny. From the subsequent publications of Ehrenberg $(1854 a, b)$ to the most recent article by Morales et al. (2012), only 19 taxonomic publications have appeared in the literature for Bolivian diatoms. These references are concentrated on the Altiplano area and the great majority deals with palaeoecological assessments on a few ecosystems that are unrepresentative even for this part of the country (see list of publications and discussion in Morales et al., 2008).

Palaeoecological works for the Altiplano frequently make reference or list taxa which include a great deal of names of species that were originally described from Europe or other continents, with only a few elements having a restricted South American origin (e.g. Bao et al., 1999; Sylvestre et al., 2001; Servant \& Servant-Vildary, 2003; Vélez et al., 2005; Ekdahl et al., 2008, among many others). The recent major taxonomical study of Andean diatoms produced by Rumrich et al. (2000) also reported a low number of new species and a surprising high number of common elements $(42 \%$ of 888 recorded taxa) with the European diatom flora (see discussion in Morales et al., 2012). These data are paradoxical for a country counted among those with the highest biological diversity in the world (Ibisch \& Mérida, 2003). Manguin (1964) expressed a similar view of predominant cosmopolitism based on samples from the Andes near Lima, Peru (ranked higher than Bolivia as a biodiverse country), reporting the presence of $52.5 \%$ of cosmopolitan taxa out of a total of 392 from 10 samples; although at least two of these samples were from below $2000 \mathrm{~m}$ above sea level (asl), indicating that they were not truly Altiplanic localities.
Morales et al. (2012) challenged this current view on Andean diatoms since their study of a single epipsammon sample from the Bolivian Desaguadero River yielded 228 taxa, more than a quarter of those reported by Rumrich et al. (2000) based on 350 samples and covering a geographical range from Argentina to Venezuela. Based on a taxonomic comparison with local regional and worldwide literature, Morales et al. (2012) determined that more than $80 \%$ of the taxa from Desaguadero River were not cosmopolitan, a fact most probably explained by the little human-related disturbance on the river collection site relative to the higher anthropic effects on the sites sampled by Rumrich et al. (2000). Although not clear from the site descriptions, it is also possible that the Peruvian localities studied by Manguin (1964) were influenced by anthropogenic effects. This is indicated by the reported proximity of such localities to Lima, smaller towns and rural communities.

Force-fitting into European and North American-based taxa concepts is an additional cause of the skewed view of the Bolivian Andean flora. As stated by Tyler (1996) and Kociolek \& Spaulding (2000), force-fitting has been a major factor in the delay of our understanding of not only algal species distribution, but also of their true identity. Theriot et al. (1985) and Van de Vijver \& Cocquyt (2009) touched on this aspect based on Peruvian samples and publications, while Morales et al. (2008; 2009) did the same for Bolivia. Force-fitting has not been exclusive to continental South America, but has also been a pervasive problem clouding diatom taxonomy and biogeography in the nearby Antarctic and sub-Antarctic regions (see discussions in Van de Vijver et al. 2010b; 2012).

Although, a high diversity of diatoms might not be common to all Altiplanic water bodies (see, for example, Álvarez-Blanco 
et al. (2011) and Patrick (1961)); the probability for the existence of more sites comparable to the Desaguadero River leaves ample room to hypothesize that a great part of the Andean diatom flora is yet unknown and that the number of endemisms and new taxa could be much higher than those currently reported in the literature (Rumrich et al., 2000; Rivera \& Cruces, 2009). In fact, the number of new taxa published from the Andean region has increased in recent years (e.g. Tapia et al., 2004; Maidana et al., 2009; Van de Vijver \& Cocquyt, 2009; Álvarez-Blanco et al., 2011; Furey et al., 2012).

The present article uses selected examples of araphid diatoms to demonstrate that misapplication of names has occurred in the diatom literature for the Bolivian Altiplano and that the implications for palaeoecological assessments could be detrimental, also producing skewed views of past environmental change. Published images of these selected taxa, identified with European names, are compared with our results of studies on type material. Although, it is not possible at present to make a reanalysis of the published palaeoecological data, mainly because the ecology of the analysed taxa is yet to be determined, some recommendations for the amendment of published data and for future taxonomic and applied studies are made.

\section{MATERIAL AND METHODS}

The following references were scanned to extract taxonomic information pertinent to the taxa used as examples in the present work: Servant-Vildary \& Blanco (1984), Servant-Vildary (1986) and Servant-Vildary \& Roux (1990). These references were chosen because they are among the few publications for the Bolivian Altiplano that contain taxonomic lists and light microscopy (LM) and scanning electron microscopy (SEM) images illustrating key taxa. Three araphid diatoms were selected to illustrate our arguments: Fragilaria (=Pseudostaurosira) brevistriata Grunow in Van Heurck, Fragilaria (=Pseudostaurosira) elliptica Schumann and Fragilaria (=Staurosirella) pinnata Ehrenberg. These taxa were selected because they are commonly reported from ecosystems around the world and seem to have been present in the Altiplano region for thousands of years as reported in, for example, Servant-Vildary \& Mello e Souza (1993) and Sylvestre et al. (2001).

Type material and original type illustrations for the three taxa mentioned above were examined (Pl. 1 herein). The type of Fragilaria brevistriata, Van Heurck slide No. 318 (Pl. 1, figs 2-4 herein) and matching raw sample (Pl. 1, fig. 1 shows a SEM image of an individual from this sample) are housed at the Botanic Garden Meise (Belgium), Department of Bryophytes and Thallophytes. The material was originally collected by Delogne from a freshwater body in Brussels, Belgium (Van Heurck, 1885). The best available description of this taxon is found in Williams \& Round (1987) and it is used here as basis for morphological discussions. In the case of Fragilaria elliptica, isotype material found at the Academy of Natural Sciences of Drexel University, in the form of a permanent slide labelled ANSP G.C. 11994 (Pl. 1, figs 6-8 herein) and raw material were analysed (SEM results are shown in Pl. 1, figs 5 and 9 herein); the original sample was collected by Schumann from Königsberg, Prussia (Schumann, 1867). For this taxon, the best description available is that of Edlund et al. (2006), upon which we base our discussions on morphology. Type material for Fragilaria pinnata is housed at the
Ehrenberg Collection, Institut für Paläontologie, Museum für Naturkunde in Berlin. This material belongs to a collection from 'Moctezuma Flüss', Mexico ('Mexiko, aus converven des Moctezuma', unknown collector), which was prepared on micas by Ehrenberg (Pl. 1, figs 11-16 herein). The original type drawings by Ehrenberg (1843, figs 8a, b, c, d, e) are shown here in Plate 1 , figure 10 , clearly matching the LM images here provided in Plate 1, figures 11-16. In this case, the descriptions presented by Haworth (1975) and Williams \& Round (1987) are used as bases for morphological discussions.

For LM analysis, Van Heurck's slide No. 318 was viewed using a Leica DMRB microscope equipped with a DC500 highresolution digital camera. Slide ANSP G.C. 11994 was analysed using a Nikon Microphot-FXA microscope equipped with a Spot Insight QE Model 4.2 Colour Digital Camera. From the Ehrenberg micas, photographs were taken at $400 \times$ using an Olympus BX51 light microscope and a Canon PowerShot A640 colour digital camera.

For SEM analysis, small portions of Van Heurck's type materials were digested with $100 \mathrm{ml}$ of hydrogen peroxide $(35 \%)$ at a temperature of $210^{\circ} \mathrm{C}$ for $36 \mathrm{~h}$. After settling and aspiration of the peroxide, $1 \mathrm{ml}$ of hydrochloric acid $(37 \%)$ was added to the samples and allowed to rest for 2-4h. Samples were rinsed at least three times with distilled water. The material was filtered and rinsed with deionized water through glass fibre filters with a $3 \mu \mathrm{m}$ pore diameter. Coating with platinum was accomplished using a BAL-TEC MED 020 Modular High Vacuum Coating System for $30 \mathrm{~s}$ at $100 \mathrm{~mA}$. A Hitachi SU-70 electron microscope operated at $5 \mathrm{kV}$ and $10 \mathrm{~mm}$ distance was used for the analysis. Also, a small portion of the Schumann isotype material was digested with nitric acid using the microwave method and washed by decanting using distilled water (Charles et al., 2002). Aliquots of clean material were air dried on to $15 \times 15 \mathrm{~cm}$ pieces of aluminum foil. Smaller pieces were trimmed and mounted on aluminum stubs with double-sided tape. The stubs were then coated with gold-palladium using a Polaron Sputter Coater for $c$. $1.5 \mathrm{~min}$ at $1.8 \mathrm{kV}$. A LeoZeiss 982-DSM electron microscope was used with an accelerating voltage of $2-4 \mathrm{kV}$.

All micrographs and scanned material were digitally manipulated and plates mounted using Photoshop CS3.

\section{RESULTS}

Plate 2 shows araphid taxa identified from Bolivian material in Servant-Vildary \& Blanco (1984), Servant-Vildary (1986) and Servant-Vildary \& Roux (1990). Plate 2, figures 17, 23b, 25-28 and 31 show organisms identified as Fragilaria brevistriata Grunow, currently considered to be the generitype of Pseudostaurosira D.M. Williams \& Round (Williams \& Round, 1987) and currently bearing the name Pseudostaurosira brevistriata (Grunow) D.M. Williams \& Round. From the figures cited above, it can be readily seen that the authors were using a very broad concept for this taxon, including in it a wide range of morphological variants. The examination of type material of Fragilaria brevistriata (P1. 1, figs 1-4) shows that none of the variants reported from the Bolivian Altiplano belong to this taxon sensu stricto. The type of $F$. brevistriata includes individuals with lanceolate shape, wider than the valves represented by ServantVildary \& Blanco (1984; P1. 2, fig. 17 herein). Besides shape and width, the striation of valves from type material is less coarse 

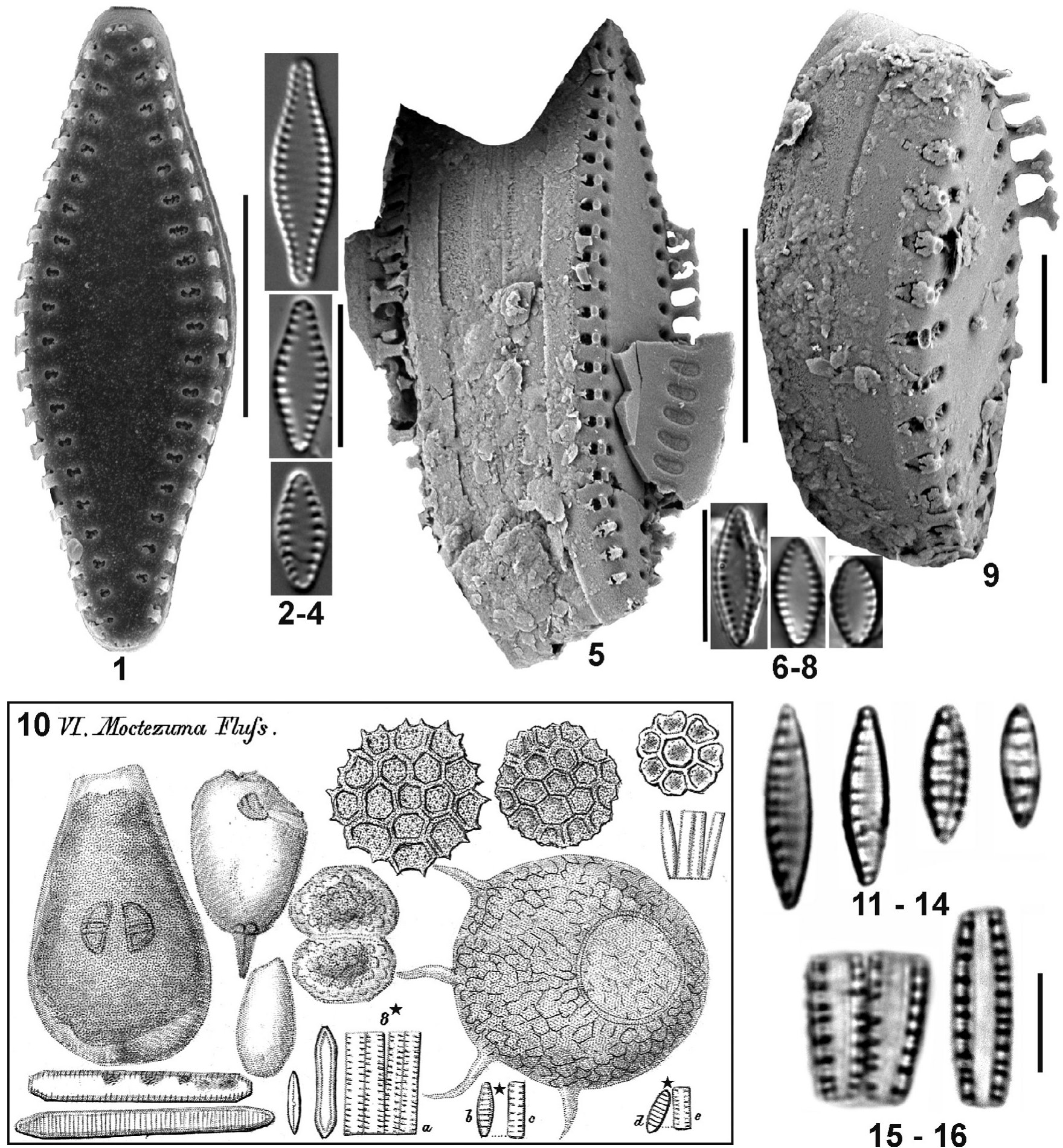

Explanation of Plate 1. figs 1-16. LM, SEM and scanned images of type material for Fragilaria brevistriata, F. elliptica and F. pinnata. fig. 1. SEM image of F. brevistriata from type material, Van Heurck No. 318, Botanic Garden Meise (Belgium); external view. figs 2-4. LM images from type material Van Heurck slide No. 318, Botanic Garden Meise (Belgium); valve views. figs 5, 9. SEM images of $F$. elliptica from isotype material housed at the Academy of Natural Sciences of Philadelphia of Drexel University; titled external views. figs 6-8. LM photographs from type material ANSP G.C. 11994 from the Academy of Natural Sciences of Philadelphia of Drexel University; valve views. fig. 10. Scanning of a portion of a plate presented in Ehrenberg (1843), illustrating material from the Moctezuma River, Mexico. Black stars mark the iconotype drawings of $F$. pinnata.

figs 11-16. LM images of several individuals from the type material of $F$. pinnata, sample 1229, Institut für Paläontologie, Museum für Naturkunde, Berlin, seen in valve (figs 11-14) and girdle view (figs 15, 16). LM scales $10 \mu \mathrm{m}$; SEM scales $1 \mu \mathrm{m}$. 

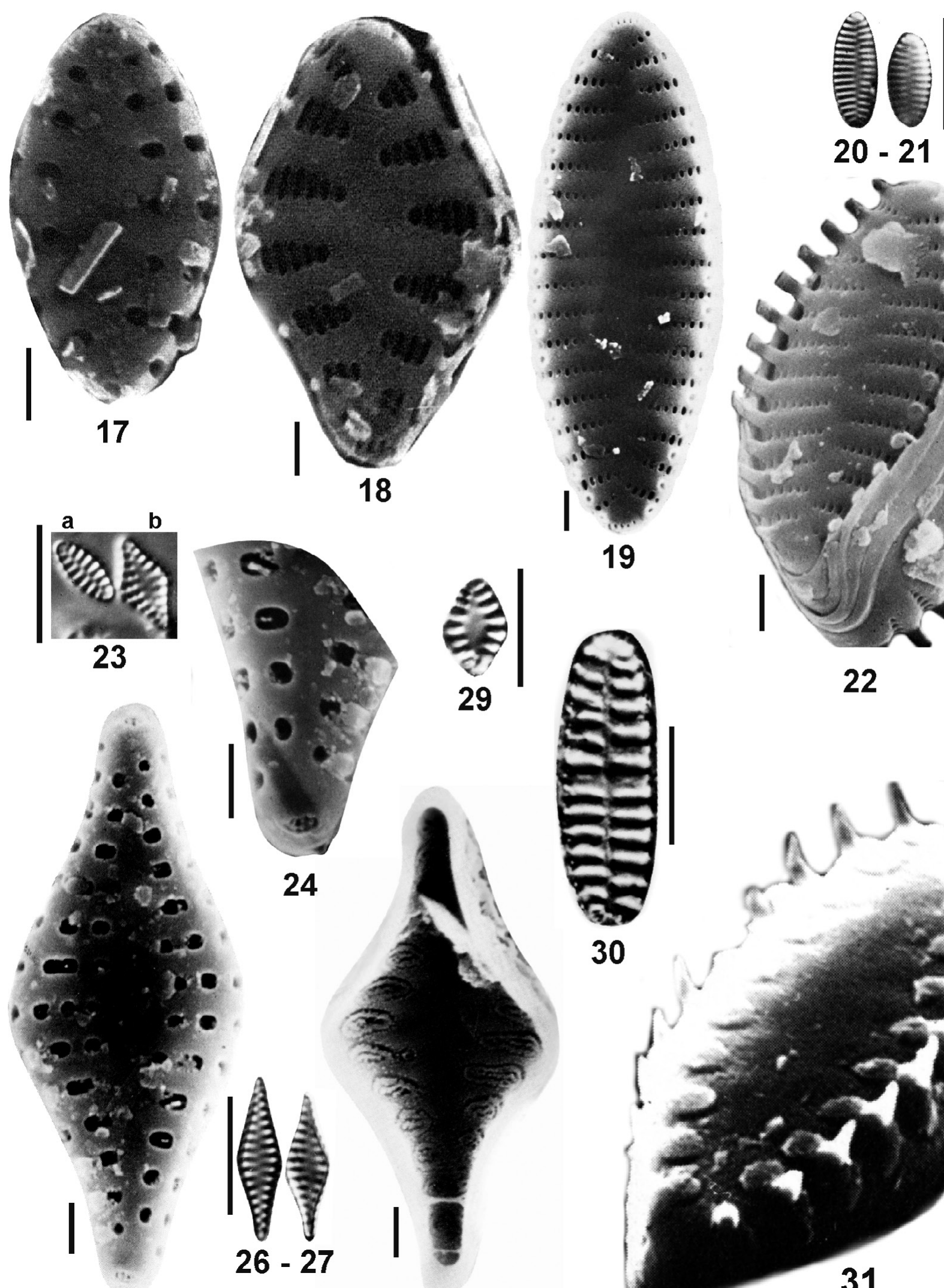

25
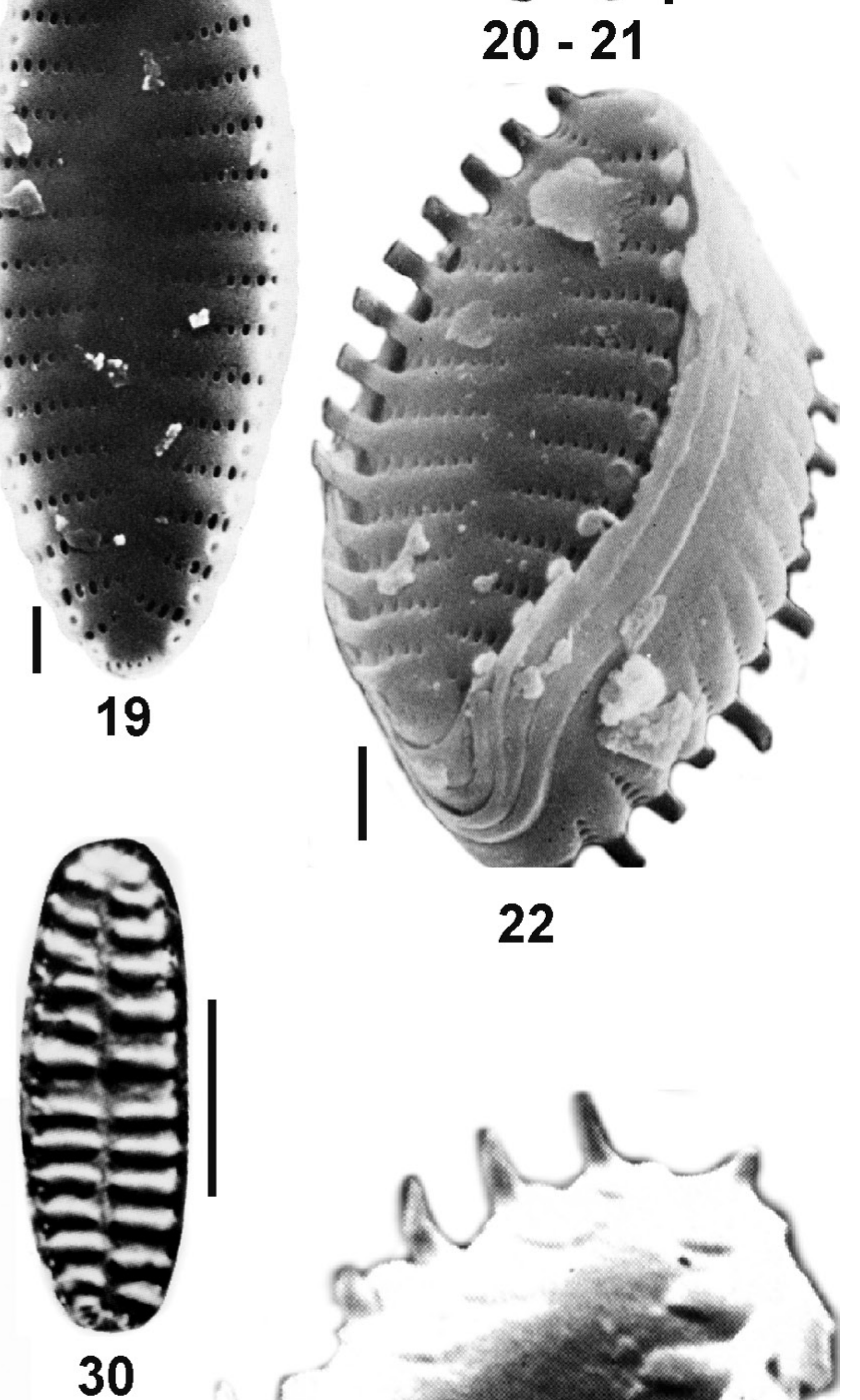
(c. 14 in $10 \mu \mathrm{m}$ ) than that in the Bolivian specimen (higher than 14 in $10 \mu \mathrm{m}$ ). The most striking difference between the type population and the Bolivian specimen is the absence of spines in the latter. Spines in species of the genus Pseudostaurosira are located between the areolae at the valve face-mantle junction. In a few species, such as Pseudostaurosira robusta (Fusey) D.M. Williams \& Round (Williams \& Round, 1987), the spines are located on the costae (between rows of areolae), but the Bolivian specimen photographed by Servant-Vildary \& Blanco (1984) does not possess spines at this location either. There are other representatives of Pseudostaurosira that have incipient spines (e.g. P. tenuis E. Morales \& Edlund (Morales \& Edlund, 2003)) or lack spines altogether (P. parasitica (W. Smith) E. Morales (Morales, 2003)), but none compares morphologically with the valve pictured from the Bolivian material. Thus, although the Bolivian specimen is certainly not $P$. brevistriata, it does indeed belong in the genus Pseudostaurosira, but currently, it cannot be associated with any known taxon within this genus.

Plate 2, figures 23b, 25 and 28 also depict representatives of Pseudostaurosira, an identification that we base on the type or areolae and apical pore fields. However, a quick comparison with Plate 1, figures 1-4 clearly shows that this second variant from Bolivian material does not belong in P. brevistriata either. Two conspicuous features that distinguish these two entities are the rhomboid shape and inconstant production of incipient spines interrupting the rows of areolae at the valve face-mantle junction in the Bolivian specimens. Rumrich et al. (2000) presented Staurosira laucensis Lange-Bertalot \& Rumrich (=Pseudostaurosira laucensis (Lange-Bertalot \& Rumrich) E. Morales \& M.L. Vis) from the Chilean Altiplano, the same geographical area as the site from where Servant-Vildary (1986) reported the specimens depicted in Plate 2, figures 23b, 25 and 28 (bottom of bog from the Ichu Khota region and downstream from outlet of Khara Khota Lake in the Bolivian Altiplano). The type of areolae, the infrequent production of incipient spines and the small apical pore fields at the valve apices readily associate $S$. laucensis with the Bolivian representatives. It should be mentioned that Servant-Vildary (1986) did not feel confident about the placement of these specimens in $F$. brevistriata and called them 'Fragilaria aff. brevistriata Grunow' in the text, further stating that the axial area was slender than that of $F$. brevistriata and that the specimens from Bolivia resembled those of Fragilaria pseudoconstruens Marciniak (now Pseudostaurosira pseudoconstruens (Marciniak) D.M. Williams \& Round). This resemblance is only in overall valve shape, however, since Fragilaria pseudoconstruens has valves with rostrate ends and inflated central area. Also, spines are well developed and located between the striae in F. pseudoconstruens (Marciniak, 1982, 1986).

A third morphological variant presented by Servant-Vildary (1986) under the name F. brevistriata is represented in Plate 2, figures 26 and 27 . The narrowly rhomboidal shape of these indi- viduals is characteristic and cannot be associated with any known araphid taxon from the literature. Since the author did not present SEM images that could be related to these LM photographs, we cannot ascribe these two individuals to a genus with confidence. Certainly, Pseudostaurosira is a candidate, but Staurosira Ehrenberg would be as well, given the LM data that do not show the structure of the striae clearly.

The fourth variant identified by Servant-Vildary \& Roux (1990) as F. brevistriata (P1. 2, fig. 31 herein) has areolae occluded externally by a rota (solid siliceous disc). This is a feature not of Pseudostaurosira, but of Pseudostaurosiropsis E. Morales (Morales, 2001). In Pseudostaurosira, the occlusions are volae, branched siliceous rods originating from the areolar inner periphery as can be seen in the type material of $P$. brevistriata (P1. 1, fig. 1). The genus Pseudostaurosiropsis has been reported from North America and Europe (Morales, 2001, 2002) and has been observed in South American collections from Brazil and Venezuela (D. Talgatti and C.E. Wetzel pers. comm.). Thus, Servant-Vildary and Roux's report of this taxon from Bolivia (though under 'Fragilaria brevistriata') is not improbable. Morales et al. (2012) related this fourth variant to Pseudostaurosira sajamaensis, but due to the regularly round characteristic of the external rota (highly irregular in P. sajamaensis), this specimen imaged by Servant-Vildary \& Roux (1990) is better placed in Pseudostaurosiropsis.

A similar comparative analysis can be presented for Fragilaria elliptica. The type material for this taxon was studied in detail by Edlund et al. (2006), who concluded that this taxon, instead of belonging to Staurosira (as had been reported in numerous previous publications from around the world), should be placed in Pseudostaurosira as P. elliptica (Schumann) Edlund, E. Morales $\&$ S.A. Spaulding. One of the reasons why this taxon had suffered such taxonomic concept drift (Van de Vijver et al., 2009, 2010a) was that only one sketch drawing had been presented by Schumann (1867, P1. 1, fig. 5), a representation that was subsequently misinterpreted and the same name misapplied to several taxa producing similar phenotypes at approximately the size of the diatoms depicted by such drawings. The proper identification of taxa with convergent morphology often requires populationlevel studies under SEM and detailed cross-checking with LM data (Morales et al., 2001). Servant-Vildary (1986) identified specimens illustrated herein in Plate 2, figures 19-22 as ' $F$. elliptica Schuman', but a comparison with type material of $F$. elliptica (Pl. 1, figs 5-9 herein) makes this identification untenable. The specimens from the Bolivian material belong in fact to Staurosira and have close affinities with $S$. venter (Ehrenberg) Cleve \& Möller, a taxon frequently reported from freshwaters around the world, but that also requires a thorough revision based on type material originally studied by Ehrenberg (1854b). Valve outline, areolae shape and structure, apical pore field and girdle features relate the Bolivian specimens to Staurosira.

Explanation of Plate 2. figs 17-31. LM and SEM images from publications based on material collected from the Bolivian Altiplano. fig. 17. Fragilaria brevistriata Grunow sensu Servant-Vildary \& Blanco (1984, pl. 3, fig. 1), external view. fig. 18. Fragilaria pinnata? Ehrenberg sensu Servant-Vildary \& Blanco (1984, pl. 3, fig. 2), external view. figs 19-22. Fragilaria elliptica Schuman sensu Servant-Vildary (1986, pl. 2, figs 23, 22, 21 and 25, respectively). fig. 23a. Fragilaria pinnata Ehrenberg sensu Servant-Vildary (1986, pl. 3, fig. 31a). figs 23b-28. Fragilaria brevistriata Grunow sensu Servant-Vildary (1986, pl. 3, figs 31b-36). fig. 29. Fragilaria pinnata Ehrenberg sensu Servant-Vildary (1986, pl. 2, fig. 30). fig. 30. Fragilaria pinnata Ehrenberg sensu Servant-Vildary (1986, pl. 8, fig. 147). fig. 31. Fragilaria brevistriata Grunow sensu Servant-Vildary \& Roux (1990, fig. 27). LM scales $10 \mu \mathrm{m}$; SEM scales $1 \mu \mathrm{m}$. 
The case of the application of the name Fragilaria pinnata is more complicated given the tangled taxonomic history of this name (Morales et al., 2013). The taxon was originally erected by Ehrenberg and its nomenclatural changes through time can be summarized as follows.

Basionym:

- Fragilaria pinnata Ehrenberg, 1843, p. 415, pl. 3 (6), figs 8a-e. Here as Plate 1, figure 10.

The name $F$. pinnata had already been used in 1841 by Ehrenberg, but it was not until 1843 that he provided a description and an illustration.

Later combinations found in the literature are:

- Odontidium pinnatum (Ehrenberg) Kützing (Kützing, 1844)

- Nematoplata pinnata (Ehrenberg) Kuntze (Kuntze, 1898).

The current name being used for this taxon is:

- Staurosirella pinnata (Ehrenberg) D.M. Williams \& Round (Williams \& Round, 1987).

A Google ${ }^{\circledR}$ search under the four names listed above yielded 45613 hits (search done on 8 September 2012). Compared to hits on the same date for some of the most commonly reported taxa in the diatom literature, such as Ulnaria ulna (Nitzsch) Compère (=Fragilaria ulna (Nitzsch) Lange-Bertalot or Synedra ulna (Nitzsch) Ehrenberg: 252900 compiled hits for the three names), Eolimna minima (Grunow) Lange-Bertalot (=Navicula minima Grunow: 66300 hits for both names), Nitzschia palea (Kützing) W. Smith (42 500 hits), and Gomphonema parvulum Kützing (and Sphenella parvula Kützing: 39560 hits for the two names), it is evident that 'pinnata' is, indeed, a widely used name. Conservatively, about 12 different morphological variants have been identified as Fragilaria pinnata or Staurosirella pinnata in the literature (consult references listed in Gaul et al. (1993) and Henderson \& Reimer (2003)). Only the site http:// craticula.ncl.ac.uk/EADiatomKey/html/taxon $13780050 . \mathrm{html}$ (accessed on 8 September 2012) has six of these variants. One of the reasons for the wide concept applied to 'pinnata' is that one of the most common and influential floras world-wide, Krammer \& Lange-Bertalot (1991), has been used as a basis for its identification. This publication presents 'pinnata' in plate 133, figs 1-18, $32,32 \mathrm{~A}$, depicting what can be arguably separated into at least nine different morphological variants. In plate 134, fig. 8, these same authors include (with a question mark) yet another variant under the epithet 'pinnata'. Although the concept used by Dr Lange-Bertalot's research group has been drastically narrowed in recent years (e.g. Hofmann et al., 2011), their shift has not been based on analysis of Ehrenberg's type material. It is not clear why the name Staurosira mutabilis (W. Smith) Grunow has suddenly started to be used for some variants formerly placed under Fragilaria pinnata (e.g. Werum \& Lange-Bertalot, 2004; Hofmann et al., 2011; Kulikovskiy et al., 2011), but it is not based on analysis of type material of Odontidium mutabile W. Smith either. Furthermore, it is not clear why the name Staurosira pinnata Ehrenberg, a different taxon altogether as can be evidenced from the type drawings in Ehrenberg (1854b), was used to replace the name Fragilaria pinnata in some publications (e.g. Rumrich et al., 2000; Schmidt et al., 2004). Needless to say, thorough LM and SEM studies of type material of Staurosira pinnata have not been done to date.

As presented by Morales et al. (2013), examination of the original type figures of Fragilaria pinnata in Ehrenberg (1843; depicted in Pl. 1, fig. 10 herein, see black stars) reveals that this author had a completely different concept of this taxon from the one, albeit wide, that is used today. Ehrenberg's drawings show valves in girdle and valve views that can be readily tied to the genus Denticula Kützing. LM analysis of the micas of $F$. pinnata confirms this association since the valve morphology, including the typically septate girdle bands, can be clearly observed (P1. 1 figs 11-14). It is unclear when and where the notorious shift in the concept of 'pinnata' occurred, but the analysis of type material puts in evidence that the application of this name to an araphid diatom is mistaken.

Servant-Vildary \& Blanco (1984) and Servant-Vildary (1986) used the epithet 'pinnata' to identify three morphological variants. Plate 2, figures 18 and 29 herein, depict the first variant. Plate 2, figure 18 was published in Servant-Vildary \& Blanco (1984) and was ascribed to 'Fragilaria pinnata? Ehr.', but no discussion on this determination is included in the text. Plate 2, figure 29 was presented two years later (Servant-Vildary, 1986) and the author discussed that this 'oval' shape (rhomboid in our view) is mixed with the rounded (elliptical in our view) more frequent form (here depicted in Pl. 2, fig. 23a). The characteristics of the striae and spines described by Servant-Vildary (1986) certainly place these two variants in Staurosirella D.M. Williams \& Round (Williams \& Round, 1987), but, as we saw earlier, ascribing any araphid diatom to 'Fragilaria pinnata' is erroneous.

The third morphological variant used by Servant-Vildary (1986) is depicted here in Plate 2, figure 30. The linear-elliptical valve outline with a narrow sternum is characteristic of the depicted specimen and sets it apart from any other taxon currently known in Fragilaria or Staurosirella and probably represents a new species. As per our analysis of the type, the inclusion of this form in 'Fragilaria pinnata' is also flawed.

\section{DISCUSSION}

Given that before our study of Van Heurck's type material the only reference to the type of $F$. brevistriata was an outline drawing in Van Heurck (1881, pl. 45, fig. 32), inclusion of several morphological variants under this name was not infrequent in the literature, Servant-Vildary's (1986) publication not being the exception (see the references reported to contain SEM images of this taxon in Gaul et al. (1993) and Henderson \& Reimer (2003) to demonstrate the wide concept currently used for 'brevistriata').

Likewise, at the time Servant-Vildary (1986) made her identifications of Altiplano material, the prevailing concept of $F$. elliptica (in the absence of type material studies) indeed included phenotypes like the ones she studied. Thus, her approach to the identification of the Bolivian specimens was the most likely given the base references she used for identification: Haworth (1975), Rosen \& Lowe (1981) and Archibald (1983).

Again, Servant-Vildary and collaborators were using the bibliography available at that time, which in turn was not based on thorough analysis of type material and simply inherited and transmitted 
a series of concepts greatly influenced by taxonomic drift. Therefore, the use of the epithet 'pinnata' by Servant-Vildary and collaborators, as used by the bulk of other authors in the literature produced from that time until recently, is a natural consequence.

As presented thus far, taxonomic drift was not the only problem during identification of Andean material, but force-fitting of populations from this geographical area to concepts and names developed for Europe and elsewhere also produced a skewed view of diatom communities in the Andes. As a consequence, today we only have a partial idea of the composition and structure of those communities and we know very little about the ecology of even the most common, non-cosmopolitan taxa. Given that South America started its separation from Europe and Africa in the Permian-Jurassic (250-145 Ma) and that the Andes have a Mesozoic-Tertiary origin (250-2.6Ma) (Oncken et al., 2006), organisms in this mountainous region have had sufficient time to evolve and produce populations isolated from other continents and from other neighbouring ecosystems in South America (e.g. the lowlands of the Amazon or the coastal Pacific strip). In the Bolivian Altiplano, the average altitude of $4000 \mathrm{~m}$ asl of the western Andean mountain range and the equally high Eastern Cordillera constitutes a formidable barrier greatly reducing gene flow, as shown by the numerous animal and higher plant endemics (Aguirre et al., 2009; Navarro, 2011). Although no comparable studies of endemism and gene flow exist for the algae, it is highly likely that similar processes occurred in populations and communities of these organisms. Therefore, use of European floras or taxonomic works for other regions of the world or even other South American ecoregions must be exercised with extreme caution (Morales et al., 2008, 2009; Van de Vijver \& Cocquyt, 2009). As we have seen in the case of araphids selected from publications for the Andes, in none of the three cases was the application of European concepts correct.

The lack of comprehensive floristic works for the Andes, works based on detailed LM and SEM analyses and cross-checking with type material, seriously affects applied fields such as ecology. The importance of having a sound taxonomic analysis prior to applied ecological interpretations can be witnessed in the literature for the Andes. In the case of $S$. pinnata, for example, there is no agreement regarding the range of ecological conditions in which this taxon can be found. While most authors agree that it is a benthic, epiphytic taxon (e.g. Cross et al., 2000; McCulloch \& Davies, 2001), regarding salinity some authors state that it is a taxon found in low $\mathrm{pH}$ and conductivity, and that it thrives in oligotrophic systems (e.g. Vélez et al., 2006), while others state that it can be found in fresh to brackish conditions with variable $\mathrm{pH}$, conductivity and trophic state (Borromei et al., 2010; Fritz et al., 2012). In Europe, this has been reported as an oligo to eutraphentic taxon, capable of growing in a wide range of salinities, but tolerating alkaline waters (Van Dam et al., 1994).

Certainly, detailed studies of current populations and communities in the diverse aquatic ecosystems existing in the Andean area will lead to a better taxonomical and ecological characterization of extant organisms with beneficial implications for palaeolimnological assessments. Based on our analysis of the three araphid examples used herein, ecological misinterpretations of past conditions (e.g. Servant-Vildary \& Mello e Souza, 1993; Sylvestre et al., 2001) can be suspect and must be reassessed in the future.
We concur with Álvarez-Blanco et al. (2011), who state that there is a large number of unidentified taxa that have yet to be described for the Andes. We add that these taxa form part of communities particular to the Andes, communities that have not yet been characterized, thus impeding at present the reassessments we recommend.

\section{CONCLUSION}

The analysis of the literature presented herein shows that misapplication of European names to taxa from the Andean Altiplano has occurred. This misapplication happened because the taxonomy of European taxa was founded on inadequate original descriptions and sketchy original figures, which in turn led to taxonomic drift. Without a clearly defined protologue, the ecology was also illdetermined, leading to a series of - often contradictory - ecological requirements for a given taxon. Palaeoecological interpretations based on such undefined taxonomy and ecology could have led to erroneous interpretations of past ecological conditions in Andean settings and, thus, a reassessment based on studies of a combination of LM, SEM and critical reviews of publications and type material is needed.

The development of a taxonomically well-founded current and fossil flora for the Andes is urgently needed. Recent studies in this geographical area, using a combination of LM and SEM tools, show that at least some locations in the Altiplano could hold an unreported taxonomic richness and endemism that could change the current view of the diatom flora in this part of the world. Future palaeoecological studies encompassing a thorough taxonomical analysis and the use of a well-founded flora could yield more accurate interpretations of past ecological conditions.

\section{ACKNOWLEDGEMENTS}

EAM thanks Donald Charles (The Academy of Natural Sciences of Drexel University, USA), Andrzej Witkowski (University of Szczecin, Poland), Taniel Danelian (Université de Lille, France), Felipe Artigas (Université du Littoral Côte d'Opale, France), Jean Prygiel (Agence de l'Eau Artois-Picardie, France) for partial travel support to participate in meetings and conduct research in Europe. We thank Friedel Hinz (Hustedt Collection, Alfred-Wegener-Institut für Polar-und Meeresforschung, Bremerhaven, Germany) and Jose María Guerrero (División Científica Ficología, Facultad de Ciencias Naturales y Museo, Universidad Nacional de La Plata, Argentina) for kindly providing the scanned Ehrenberg plate and LM photographs of F. pinnata, respectively.

\section{Manuscript received 7 April 2014 \\ Manuscript accepted 7 April 2014}

Scientific editing by Taniel Danelian.

\section{REFERENCES}

Aguirre, L.F., Aguayo, R., Balderrama, J., Cortez, C. \& Tarifa, T. (Eds) 2009. Libro Rojo de La Fauna Silvestre De Vertebrados De Bolivia. Ministerio de Medio Ambiente y Agua. La Paz, Bolivia, 571pp.

Álvarez-Blanco, I., Cejudo-Figueiras, C., de Godos, I., Muñoz, R. \& Blanco, S. 2011. Las diatomeas de los salares del Altiplano boliviano: Singularidades florísticas. Boletín de la Real Sociedad Española de Historia Natural Sección Biología, 105: 67-82.

Archibald, R.E.M. 1983. The diatoms of the Sundays and Great Fish rivers in the Eastern Cape Province of South Africa. Bibliotheca Diatomologica, 1: 1-362. 
Bao, R., Sáez, A., Servant-Vildary, S. \& Cabrera, L. 1999. Lake-level and salinity reconstruction from diatom analyses in Quillagua formation (late Neogene, Central Andean forearc, northern Chile). Palaeogeography, Palaeoclimatology, Palaeoecology, 153: 309-335.

Borromei, A.M., Coronato, A., Franzén, L.G. et al. 2010. Multiproxy record of Holocene paleoenvironmental change, Tierra del Fuego, Argentina. Palaeogeography, Palaeoclimatology, Palaeoecology, 286: $1-16$.

Charles, D.F., Knowles, C. \& Davis, R.S. (Eds) 2002. Protocols for the Analysis of Algal Samples Collected as Part of the U.S. Geological Survey National Water-Quality Assessment Program. Patrick Center for Environmental Research-Phycology Section, the Academy of Natural Sciences of Philadelphia. Report No. 02-06, 124pp.

Cross, S.L., Baker, P.A., Seltzer, G.O., Fritz, S.C. \& Dunbar, R.B. 2000. A new estimate of the Holocene lowstand level of Lake Titicaca, central Andes, and implications for tropical palaeohydrology. The Holocene, 10: $21-32$.

Edlund, M.B., Morales, E.A. \& Spaulding, S.A. 2006. The type and taxonomy of Fragilaria elliptica Schumann, a widely misconstrued taxon. In Witkowski, A. (Ed.), Proceedings of the Eighteenth International Diatom Symposium. Biopress Limited, Bristol, 53-59.

Ehrenberg, C.G. 1841. Über Verbreitung und Einfluss des mikroskopischen Lebens in Süd- und Nordamerika. Bericht über die zur Bekanntmachung geeigneten Verhandlungen der Königlich-Preussischen Akademie der Wissenschaften zu Berlin, 1841: 139-144.

Ehrenberg, C.G. 1843. Verbreitung und Einflufs des mikroskopischen Lebens in Süd-und Nord-Amerika. Abhandlungen der Königlichen Akademie der Wissenschaften zu Berlin, 1841: 291-445.

Ehrenberg, C.G. 1854a. Mikrogeologie. Das Erden und Felpen schaffende wirken des unsichtbar kleinen selbstständigen Lebens auf der Erde. Leopold Voss, Leipzig, 374pp.

Ehrenberg, C.G. 1854b. Mikrogeologie. Einundvierzig Tafeln mit über viertausend grossentheils colorirten Figuren, Gezeichnet vom Verfasser [Atlas]. Leopold Voss, Leipzig, 40 pls.

Ekdahl, E.J., Fritz, S.C., Bake, P.A., Rigsby, C.A. \& Coley, K. 2008. Holocene multidecadal-to millennial-scale hydrologic variability on the South American Altiplano. The Holocene, 18: 867-876.

Fritz, S.C., Baker, P.A., Tapia, P., Spanbauer, T. \& Westover, K. 2012. Evolution of the Lake Titicaca basin and its diatom flora over the last $\sim 370,000$ years. Palaeogeography, Palaeoclimatology, Palaeoecology, 317-318: 93-103.

Furey, P.C., Mayama, S., Lowe, R.L. \& Catenazzi, A. 2012. Frankophila wayqechae sp. nov., a new aerophilic diatom species from the Peruvian Andes, South America. Diatom Research, 27: 165-175.

Gaul, U., Geissler, U., Henderson, M., Mahoney, R. \& Reimer, C.W. 1993. Bibliography on the fine-structure of diatom frustules (Bacillariophyceae). Proceedings of the Academy of Natural Sciences of Philadelphia, 144: 69-238.

Haworth, E.Y. 1975. A scanning electron microscope study of some different frustule forms of the genus Fragilaria found in Scottish late-glacial sediments. British Phycological Journal, 10: 73-80.

Henderson, M.V. \& Reimer, C.W. 2003. Bibliography on the fine structure of diatom frustules (Bacillariophyceae). II. (+Deletions, addenda and corrigenda for bibliography I). Diatom Monographs, 3: 1-372.

Hofmann, G., Werum, M. \& Lange-Bertalot, H. 2011. Diatomeen im Süßwasser-Benthos von Mitteleuropa. Bestimmungsflora Kieselalgen für die ökologische Praxis. Über 700 der häufigsten Arten und ihre Ökologie. A.R.G. Gantner Verlag K.G., Rugell, 908pp.

Ibisch, P. \& Mérida, G. 2003. Biodiversidad: La riqueza de Bolivia. Estado del conocimiento y conservación. Editorial Fundación Amigos de la Naturaleza (FAN). Santa Cruz, Bolivia, 638pp.

Kociolek, J.P. \& Spaulding, S.A. 2000. Freshwater diatom biogeography. Nova Hedwigia, 71: 223-241.

Krammer, K. \& Lange-Bertalot, H. 1991. Bacillariophyceae. 3. Teil: centrales, Fragilariaceae, Eunotiaceae. In Ettl, H., Gerloff, J., Heynig, H. \&
Mollenhauer, D. (Eds), Süßwasserflora von Mitteleuropa, 2/3. Gustav Fisher Verlag, Stuttgart, 1-576.

Kulikovskiy, M.S., Genkal, S.I. \& Mikheyeva, T.M. 2011. New data on Bacillariophyta of Belarussia. 2. Fam. Fragilariaceae (Kütz.) De Tony, Diatomaceae Dumort. and Tabellariaceae F. Schütt. Algologia, 21: 357-373.

Kuntze, O. 1898. Revisio Generum Plantarum. Part III. Leipzig, 576pp.

Kützing, F.T. 1844. Die kieselschaligen Bacillarien oder Diatomeen. Nordhausen, 152pp.

Maidana, N.I., Seeligmann, C. \& Morales, M. 2009. Bacillariophyceae del Complejo Lagunar Vilama (Jujuy, Argentina). Boletín de la Sociedad Argentina de Botánica, 44: 257-271.

Manguin, E. 1964. Contribution à la connaissance des diatomées des Andes du Pérou. Mémoires du Muséum d'Histoire Naturelle, Série B, Botanique, 12: 41-98.

Marciniak, B. 1982. Late Glacial and Holocene new diatoms from a glacial Lake Przedni Staw in the Pięć Stawów Polskich Valley, Polish Tatra Mts. Acta Geologica Academiae Scientiarum Hungaricae, 25: 161-171.

Marciniak, B. 1986. Late Quaternary diatoms in the sediments of Przedni Staw Lake (Polish Tatra Mountains). Hydrobiologia, 143: 255-265.

McCulloch, R.D. \& Davies, S.J. 2001. Late-Glacial and Holocene palaeoenvironmental change in the central Strait of Magellan, southern Patagonia. Palaeogeography, Palaeoclimatology, Palaeoecology, 173: 143-173.

Montagne, C. 1839. Botanique. Seconde Partie. Florula Boliviensis. Stirpes Novae vel minus cognitae. Plantae Cellulares. In d'Orbigny, A. (Ed.), Voyage dans l'Amérique Méridionale. Tome Septième, 1ère et 2ème parties: Cryptogamie. Libraire de la Société Géologique de France, Strasbourg, 119pp.

Morales, E.A. 2001. Morphological studies in selected fragilarioid diatoms (Bacillariophyceae) from Connecticut waters (U.S.A.). Proceedings of the Academy of Natural Sciences of Philadelphia, 151: 105-120.

Morales, E.A. 2002. Studies in selected fragilarioid diatoms of potential indicator value from Florida (USA) with notes on the genus Opephora Petit (Bacillariophyceae). Limnologica, 32: 102-113.

Morales, E.A. 2003. On the taxonomic status of the genera Belonastrum and Synedrella proposed by Round and Maidana, 2001. Cryptogamie, Algologie, 24: 277-288.

Morales, E.A. \& Edlund, M.B. 2003. Studies in selected fragilarioid diatoms (Bacillariophyceae) from Lake Hovsgol, Mongolia. Phycological Research, 51: 225-239.

Morales, E.A., Siver, P.A. \& Trainor, F.R. 2001. Identification of diatoms (Bacillariophyceae) during ecological assessments: comparison between light microscopy and scanning electron microscopy techniques. Proceedings of the Academy of Natural Sciences of Philadelphia, 151: 95-103.

Morales, E.A., Fernández, E., Fernandez, C.E., Lizarro, D. \& Alcoreza, P. 2008. Algal studies in Bolivia: a compilation and preliminary analysis of existing phycological literature. Gayana Botánica, 65: 93-109.

Morales, E.A., Fernández, E. \& Kociolek, P.J. 2009. Epilithic diatoms (Bacillariophyta) from cloud forest and alpine streams in Bolivia, South America 3: diatoms from Sehuencas, Carrasco National Park, Department of Cochabamba. Acta Botanica Croatica, 68: 263-283.

Morales, E.A., Novais, M.H., Chávez, G., Hoffmann, L. \& Ector, L. 2012. Diatoms (Bacillariophyceae) from the Bolivian Altiplano: three new araphid species from the Desaguadero River draining Lake Titicaca. Fottea, 12: 41-58.

Morales, E.A., Guerrero, J.M., Wetzel, C.E., Sala, S. \& Ector, L. 2013. Unraveling the identity of Fragilaria pinnata Ehrenberg and Staurosira pinnata Ehrenberg: research in progress on a convoluted story. Cryptogamie Algologie, 34: 89-102.

Navarro, G. 2011. Clasificación de la vegetación de Bolivia. Centro de Ecología Difusión Simón I. Patiño, Santa Cruz, Bolivia, 713pp.

Oncken, O., Chong, G. et al. (Eds) 2006. The Andes. Active subduction orogeny. Frontiers in Earth Sciences Series, I. Springer, Berlin, 592pp. 
Patrick, R. 1961. Diatoms (Bacillariophyceae) from the alimentary tract of Phoenicoparrus jamesi (Sclater). Postilla, 49: 43-50.

Rivera, P. \& Cruces, F. 2009. Diatomeas (Bacillariophyceae) de zonas andinas del norte de Chile: nueva localidad geográfica para Haloroundia speciosa (Hustedt) Diaz et Maidana. Gayana Botánica, 66: 280-282.

Rosen, B.H. \& Lowe, R.L. 1981. Valve ultrastructure of some confusing Fragilariaceae. Micron, 22: 293-294.

Rumrich, U., Lange-Bertalot, H. \& Rumrich, M. 2000. Diatomeen der Anden. Von Venezuela bis Patagonien/Feuerland. Diatoms of the Andes. From Venezuela to Patagonia/Tierra del Fuego. Iconographia Diatomologica, 9: 1-649.

Schmidt, R., Kamenik, C., Lange-Bertalot, H. \& Klee, R. 2004. Fragilaria and Staurosira (Bacillariophyceae) from sediment surfaces of 40 lakes in the Austrian Alps in relation to environmental variables, and their potential for palaeoclimatology. Journal of Limnology, 63: 171-189.

Schumann, J. 1867. Preussische Diatomeen. Schriften der Königlichen Physikalisch-Ökonomischen Gesellschaft zu Königsberg 8: 37-68.

Servant, M. \& Servant-Vildary, S. 2003. Holocene precipitation and atmospheric changes inferred from river paleowetlands in the Bolivian Andes. Palaeogeography, Palaeoclimatology, Palaeoecology, 194: 187-206.

Servant-Vildary, S. 1986. Les diatomées actuelles des Andes de Bolivie (Taxonomie, écologie). Cahiers de Micropaléontologie, 1: 99-124.

Servant-Vildary, S. \& Blanco, M. 1984. Les diatomées fluvio-lacustres plio-pléistocènes de la Formation Charaña (Cordillère occidentale des Andes, Bolivie). Cahiers O.R.S.T.O.M. série Géologie, 14: 55-102.

Servant-Vildary, S. \& Mello e Souza, S.H. 1993. Palaeohydrology of the Quaternary saline Lake Ballivian (southern Bolivian Altiplano) based on diatom studies. International Journal for Salt Lake Research, 2: 69-85.

Servant-Vildary, S. \& Roux, M. 1990. Multivariate analysis of diatoms and water chemistry in Bolivian saline lakes. Hydrobiologia, 197: 267-290.

Sylvestre, F., Servant-Vildary, S. \& Roux, M. 2001. Diatom-based ionic concentration and salinity models from the south Bolivian Altiplano (15-23으. Journal of Paleolimnology, 25: 279-295.

Tapia, P.M., Theriot, E.C., Fritz, S.C., Cruces, F. \& Rivera, P. 2004. Distribution and morphometric analysis of Cyclostephanos andinus comb. nov., a planktonic diatom from the central Andes. Diatom Research, 19: 311-327.

Theriot, E., Carney, H.J. \& Richerson, P.J. 1985. Morphology, ecology and systematics of Cyclotella andina sp. nov. (Bacillariophyceae) from Lake Titicaca, Peru-Bolivia. Diatom Research, 24: 381-387.
Tyler, P.A. 1996. Endemism in freshwater algae. Hydrobiologia, 336: $127-135$.

Van Dam, H., Mertens, A. \& Sinkeldam, J. 1994. A coded checklist and ecological indicator values of freshwater diatoms from The Netherlands. Netherlands Journal of Aquatic Ecology, 28: 117-133.

Van de Vijver, B. \& Cocquyt, C. 2009. Four new diatom species from La Calera hot spring in the Peruvian Andes (Colca Canyon). Diatom Research, 24: 209-223.

Van de Vijver, B., Lange-Bertalot, H. \& Compère, P. 2009. Two new freshwater diatom species (Bacillariophyceae) from a small pool in the National Botanic Garden of Belgium. Belgium Journal of Botany, 142: 194-203.

Van de Vijver, B., Mataloni, G., Stanish, L. \& Spaulding, S.A. $2010 a$. New and interesting species of the genus Muelleria (Bacillariophyta) from the Antarctic region and South Africa. Phycologia, 49: 22-41.

Van de Vijver, B., Sterken, M. et al. 2010b. Four new non-marine diatom taxa from the Subantarctic and Antarctic regions. Diatom Research, 25: 431-443.

Van de Vijver, B., Tavernier, I., Kellog, T.B., Gibson, J., Verleyen, E., Vyverman, W. \& Sabbe, K. 2012. Revision of type materials of Antarctic diatom species (Bacillariophyta) described by West \& West (1911), with the description of two new species. Fottea, 12: 149-169.

Van Heurck, H. 1881. Synopsis des Diatomées de Belgique. Atlas. Ducaju \& Cie, Anvers, pls 31-77.

Van Heurck, H. 1885. Synopsis des Diatomées de Belgique. Texte. Martin Brouwers \& Co., Anvers, 235pp.

Vélez, M.I., Berrío, J.C., Hooghiemstra, H., Metcalfe, S. \& Marchant, R. 2005. Paleoenvironmental changes during the last ca. 8590 calibrated $\mathrm{yr}$ (7800 radiocarbon yr) in the dry forest ecosystem of the Patía Valley, Southern Colombian Andes: A multiproxy approach. Palaeogeography, Palaeoclimatology, Palaeoecology, 216: 279-302.

Vélez, M.I., Hooghiemstra, H., Metcalfe, S., Wille, M. \& Berrío, J.C. 2006. Late Glacial and Holocene environmental and climatic changes from a limnological transect through Colombia, northern South America. Palaeogeography, Palaeoclimatology, Palaeoecology, 234: 81-96.

Werum, M. \& Lange-Bertalot, H. 2004. Diatoms in springs from central Europe and elsewhere under the influence of hydrogeology and anthropogenic impacts. Iconographia Diatomologica, 13: 1-417.

Williams, D.M. \& Round, F.E. 1987. Revision of the genus Fragilaria. Diatom Research, 2: 267-288. 


\section{TAKE THAT NEXT STEP TO FAST TRACK YOUR CAREER...BECOME A CHARTERED GEOLOGIST OR CHARTERED SCIENTIST}

- A peer reviewed process which requires a high standard of knowledge, competence and professionalism

- The hallmark of professional achievement, recognised in the UK and in an expanding number of countries

- Identifies you as competent and professional in your chosen speciality, and binds you to an enforced Code of Conduct

- $\quad$ Recognises your achievement within your industry and among your peers

- In some sectors Chartered Geologists can sign off legal papers and reports

- Chartered Geologist makes you eligible to apply for the title of European Geologist
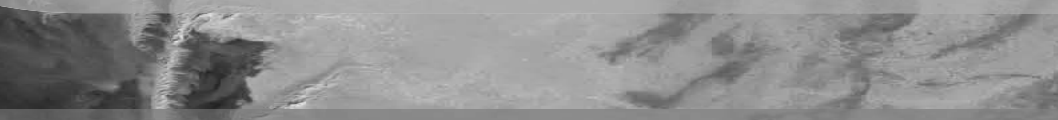

Contact us today and request an information pack to charter your flight to success

www.geolsoc.org.ti//chaptership:

Fellowship Department, The Geological Society, Burlington House, Piccadilly, London W1J OBG

Tel: 02074349944 Fax: 02074398975

Email: 